\title{
Epidemiology of Female Breast Cancer in Ogun State: Intra- and Inter-regional Discuss
}

\author{
Jude Ogechukwu Okoye ${ }^{1, *}$, Charles Erinle², Nnodimele Onuigbo Atulomah ${ }^{3}$, \\ Oluwaseun Kelechi Adeleke ${ }^{1}$
}

\author{
${ }^{1}$ Medical Laboratory Science Department, School of Public and Allied Health, Babcock University, Ogun State, Nigeria \\ ${ }^{2}$ Department of Surgery and Family Medicine, State Hospital Shokenu, Abeokuta, Ogun State, Nigeria \\ ${ }^{3}$ Department of Public Health, School of Public and Allied Health, Babcock University, Nigeria
}

Copyright $\bigcirc 2017$ by authors, all rights reserved. Authors agree that this article remains permanently open access under the terms of the Creative Commons Attribution License 4.0 International License

\begin{abstract}
This study determined the prevalence of breast cancer in relation to age, reproductive status and population of Ogun State. Out of a total of 816 human cancer presentations observed between 2012 and 2016, 334 $(40.9 \%)$ female breast cancer (with age range $=23$ to 95 years and mean age $=50.3$ years) were retrospectively reviewed. Result revealed five breast cancer types: Invasive ductal carcinoma (IDC), ductal carcinoma in situ (DCIS), Paget cell disease, medullary carcinoma and mucinous carcinoma. Invasive ductal carcinoma was the predominant breast cancer type (94.9\%) while year 2016 had the highest number of breast cancer presentations $(47 \%)$ at $\mathrm{p}<0.001)$. Result also showed that age range of 41-50 years and 61-70 years had the highest prevalence and incidence of breast cancer, respectively $(p<0.001)$. Reproductive age (23-45 years) had the highest frequency of invasive ductal carcinoma and Paget cell disease when compared with other age groups $(\mathrm{p}<0.001)$. Result also showed interesting differences in prevalence of breast cancer types in Ogun State compared with other regions. The result revealed that IDC, DCIS, Medullary carcinoma, Mucinous carcinoma and Paget's cell disease are more prevalent in South-West, South-East, North-West, South-East, North-Central regions, respectively. In conclusion, our findings suggest that breast cancer occurrence is greatly influence by age, reproductive status and location.
\end{abstract}

Keywords Age, Female Breast Cancer, Geopolitical Zones, Nigeria, Prevalence, Age

\section{Introduction}

Breast cancer is the most common malignancy found among women across the world [1]. It has a prevalence of $27 \%, 15 \%$ and $46 \%$ in North African countries,
sub-Saharan Africa and Nigeria, respectively [2]. Recent studies have shown that it is the leading cause of death among women of African descent, especially in Lagos $(25-28 \%)[3,4]$. About $40 \%$ of the deaths occur within the age range of 41-60 years [4]. This could be due to the fact that breast cancers in Africa, particularly West Africa, are predominantly triple hormone receptor-negative tumours (27\%) which have been known to have poor prognosis [5]. Risk factors associated with breast cancer include: mutation in BRCA1/BRCA2 genes, advancing age, malnutrition, alcohol consumption, family history of breast cancer, obesity, hormonal factors, early menarche (before the age of 12), late menopause, prior breast biopsy, older age at first birth, induced abortion, use of contraceptives, premature menopause (especially in women below the age of menopause), overweight and endogenous hormone (especially in premenopausal women) [6-9]. Since there is paucity of data comparing the prevalence of breast cancer and its subtypes in the six geopolitical zones of Nigeria, reducing breast cancer related death might prove abortive as interventions may not be appropriately channeled to areas of high incidence and prevalence. Thus, this study was carried out to bridge the gap in literature in relation to prevalence of breast cancer types in Ogun State.

\section{Material and Methods}

\subsection{Population Setting}

This study included all breast cancer cases recorded in State Hospital Abeokuta and Federal Medical Centre and some other health care facilities in Shagamu metropolis, all in Ogun State. These hospitals serve people in Ogun State and other bordering States such as Ondo, Lagos and Oyo States, and Republic of Benin. 


\subsection{Study Design}

This retrospective study included breast cancer cases documented from 2012 through 2016 in Ogun State. It compared the prevalence of breast cancer among other human cancer presentations and the distribution of breast cancer subtypes in the State. Data collected were divided into 4 groups, designated: Group 1 (reproductive age or child bearing women), Group 2 (pre-menopausal age women), Group 3 (menopausal age women) and Group 4 (post-menopausal age women). The cases were also categorized into the age ranges of 21-30 to $91-100$ years. Male breast cancer cases were excluded from this study. Ethical clearances were obtained from State Hospital Abeokuta Health Research Ethics Committee (SHA/RES/VOL.2/178) and Babcock University Health Research Ethics Committee (BUHREC372/17) before the commencement of this study.

\subsection{Statistical Analysis}

Data generated from this study was subjected to descriptive statistics and student $\mathrm{t}$-tests to compare the differences between breast cancer of child bearing, pre-menopausal, menopausal and post-menopausal women. Comparison between the years and breast cancer types were also carried out. Significant level was set at $\mathrm{p}<0.001$.

\section{Results}

The mean and median ages of the patients were 50.3 and 48 years, respectively.

Figure 2 showed that IDC, DCIS, Medullary carcinoma, Mucinous carcinoma and Paget's cell disease are more prevalent in South-West, South-East, North-West, South-East, North-Central regions, respectively.

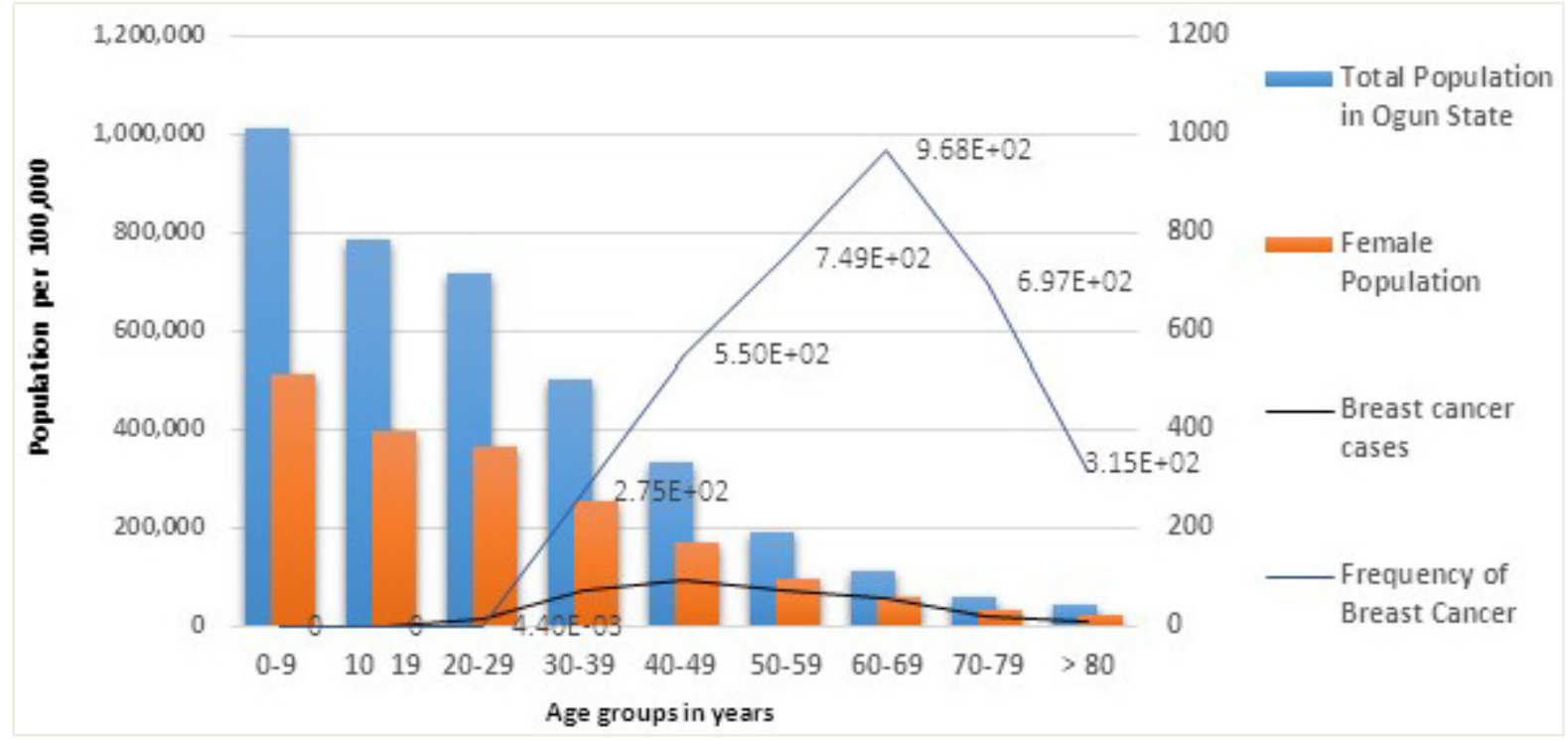

Figure 1. Population based age range-Breast cancer distribution in Ogun State

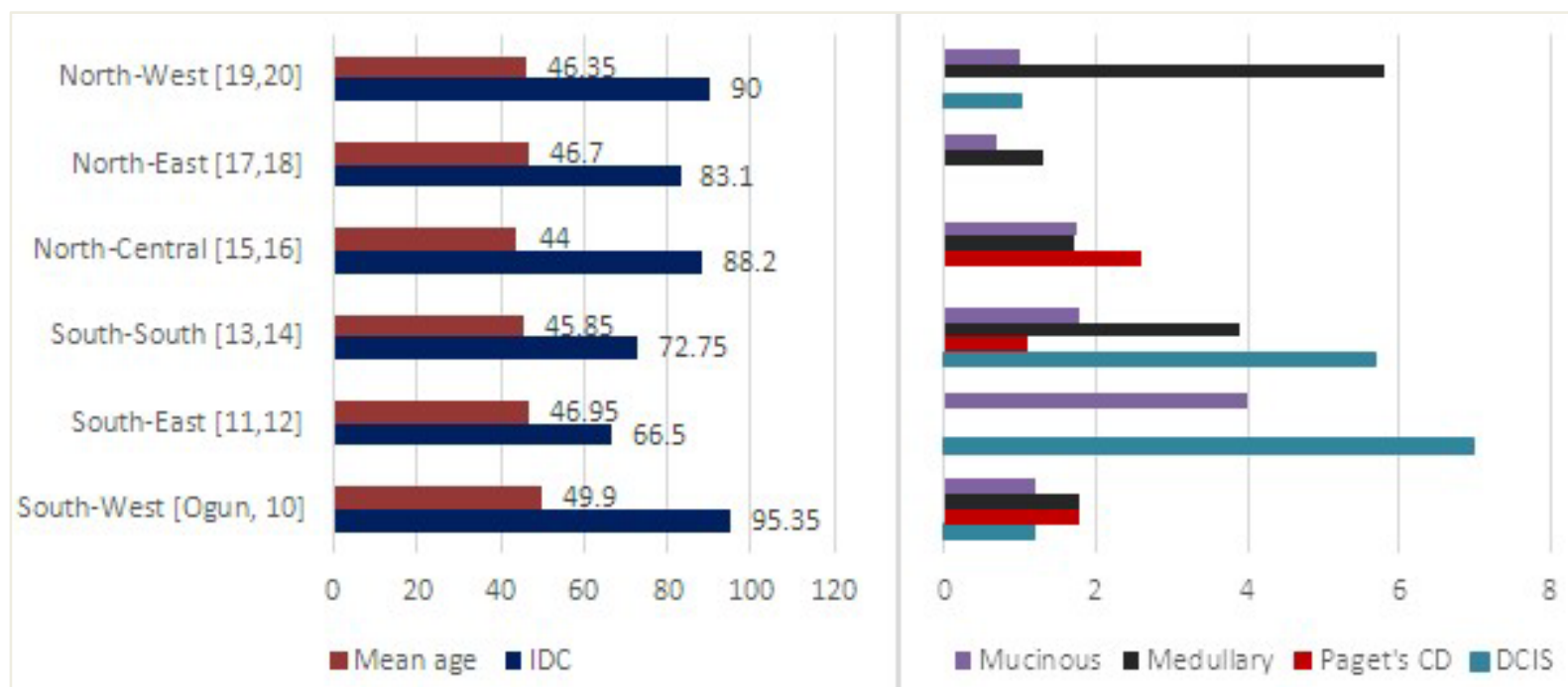

Keys: Invasive ductal carcinoma (IDC), ductal carcinoma in situ (DCIS), Paget cell disease, medullary carcinoma and mucinous carcinoma

Figure 2. Distribution of breast cancer subtypes in the six geopolitical zones of Nigeria in relation to mean age. 
Table 1. Percentage and frequencies of female Breast cancer among other recorded type of human cancers in respect to years

\begin{tabular}{|c|c|c|c|c|c|c|c|}
\hline Years & $\begin{array}{l}\text { Total № of } \\
\text { Cancers } \\
\text { (n) }\end{array}$ & $\begin{array}{c}\text { Breast } \\
\text { cancer } \\
(\mathrm{BC})\end{array}$ & $\begin{array}{c}\text { Percentage } \\
\text { (BC/n\%) }\end{array}$ & $\begin{array}{c}\text { Frequency } \\
\left(\mathbf{B C} / \mathbf{N}_{2} \%\right) \\
\mathrm{N}_{1}=334\end{array}$ & $\begin{array}{c}\text { Frequency } \\
\left(\mathrm{BC} / \mathrm{N}_{1} \%\right) \\
\mathrm{N}_{2}=\mathbf{8 1 6}\end{array}$ & $\mathbf{T}$ & p-value \\
\hline 2012 & 149 & 61 & 41.1 & 17.2 & 18.3 & & \\
\hline 2013 & 151 & 57 & 37.7 & 20.6 & 18.5 & & \\
\hline 2014 & 107 & 41 & 38.3 & 13.0 & 13.1 & -18.286 & 0.000 \\
\hline 2015 & 179 & 67 & 37.4 & 21.4 & 21.9 & & \\
\hline 2016 & 230 & 108 & 47.0 & 27.7 & 28.2 & & \\
\hline
\end{tabular}

Keys: №= Number; $\mathrm{BC}=$ Breast cancer; $\mathrm{N}_{1}=$ Total female breast cancer cases; $\mathrm{N}_{2}=$ Total number of human cancer presentations (Independent $\mathrm{T}$ test)

Table 1 above reveals increasing number of human cancers in Ogun State from 2012 through 2016, except for the drop between 2014. A total of 816 human cancer cases were recorded within the stated periods, out of which 334 representing $40.9 \%$ were breast cancer cases. The table also shows that the percentage of breast cancer to the total number human cancers was 61(41.1\%) in 2012, 57(37.7\%) in 2013, $41(38.3 \%)$ in 2014, 67(37.4\%) in 2015 and $108(47 \%)$ in 2016. It could be deduced from the table that the frequency of breast cancer is relatively on the increase in recent times and highest in 2016. The table shows significant difference in the breast cancer recorded within the periods of assessed 5 years $(\mathrm{p}<0.001)$

Table 2 below reveals that out of the 334 breast cancer cases recorded within the stated periods, $1(0.3 \%)$ was mucinous breast cancer, 6(1.8\%) were medullary breast cancer, 6(1.8\%) were Paget's disease and 317(94.9\%) were invasive breast cancer. From this result, it could be deduced that invasive ductal carcinoma was most prevalent breast cancer type among other types of breast cancer $(\mathrm{p}<0.001)$.

Table 2. Frequency distribution of breast cancer by histological types

\begin{tabular}{|c|c|c|c|c|c|c|c|c|c|c|c|}
\hline Types of BC & Total № BC & $21-30$ & $31-40$ & $41-50$ & $51-60$ & $61-70$ & $71-80$ & $81-90$ & $91-100$ & $\mathbf{T}$ & p-value \\
\hline IDC & $317(94.9)$ & $16(5.0)$ & $66(20.8)$ & $88(27.8)$ & $66(20.8)$ & $54(17.0)$ & $22(6.9)$ & $3(0.9)$ & $4(1.3)$ & \multirow{6}{*}{16.705} & \multirow{6}{*}{0.000} \\
\hline DCIS & $4(1.2)$ & 0 & $2(50.0)$ & $0(0.0)$ & $2(50.0)$ & 0 & 0 & 0 & 0 & & \\
\hline Paget's Disease & $6(1.8)$ & 0 & $1(16.7)$ & $3(50.0)$ & $2(33.3)$ & 0 & 0 & 0 & 0 & & \\
\hline Medullary & $6(1.8)$ & 0 & $1(16.7)$ & $1(16.7)$ & $2(33.3)$ & $2(33.3)$ & 0 & 0 & 0 & & \\
\hline Mucinous C. & $1(0.3)$ & 0 & 0 & $1(100)$ & 0 & 0 & 0 & 0 & 0 & & \\
\hline Total & $334(100)$ & 16 & 70 & 93 & 72 & 66 & 22 & 3 & 4 & & \\
\hline
\end{tabular}

Keys: $\mathrm{BC}=$ Breast cancer (\%) ; IDC= Invasive ductal Carcinoma; DCIS= Ductal Carcinoma in situ; $\mathrm{C}=$ Carcinoma (Independent T-Test)

Based on reproductive status (last menstrual period), table 3 shows that out of the 334 breast cancer cases recorded, post-menopausal, menopausal, premenopausal and reproductive women had breast cancer prevalence of $47(14.8 \%)$, $71(21.1 \%), 87(25.8 \%)$ and $129(41.2 \%)$. Based on reproductive age (conventional classification), the table also shows that the age ranges of $23-45$ years, $46-55$ years, $56-65$ years and $\geq 66$ years had breast cancer frequency of $42.9 \%, 25 \%, 17.9 \%$ and $14.3 \%$, respectively. From this result, it could be deduced that breast cancer was more common among reproductive women ( $\leq 45$ years) compared with other women ( $\geq 46$ years). The table also shows that women of child bearing age, who are below the age of 45 years, were at a higher risk of developing invasive ductal carcinoma and Paget's disease compared with women in other groups. 
Table 3. Distribution of breast cancer by reproductive status and histological type

\begin{tabular}{|c|c|c|c|c|c|c|c|c|c|}
\hline Reproductive status & $\begin{array}{c}\text { № of } \\
\text { BC }\end{array}$ & $\begin{array}{l}\text { \% of } \\
\text { BC }\end{array}$ & IDC & DCIS & $\begin{array}{l}\text { Paget's } \\
\text { disease }\end{array}$ & $\begin{array}{c}\text { Medullary } \\
\text { Disease }\end{array}$ & M.C. & F-value & P-value \\
\hline Reproductive (Child bearing) & 129 & 38.3 & 122 & 1 & 4 & 1 & 1 & \multirow{5}{*}{12.898} & \multirow{5}{*}{0.000} \\
\hline Premenopausal & 87 & 25.8 & 81 & 3 & 1 & 2 & 0 & & \\
\hline Menopausal & 71 & 21.1 & 69 & 0 & 1 & 1 & 0 & & \\
\hline Postmenopausal & 47 & 14.8 & 45 & 0 & 0 & 2 & 0 & & \\
\hline Total & 334 & 100 & 317 & 4 & 6 & 6 & 1 & & \\
\hline \multicolumn{10}{|l|}{ Reproductive age } \\
\hline $23-45$ years & 144 & 42.9 & 135 & 2 & 5 & 1 & 1 & & \\
\hline $46-55$ years & 84 & 25.0 & 80 & 2 & 0 & 2 & 0 & \multirow{4}{*}{-24.347} & \multirow{4}{*}{0.000} \\
\hline $56-65$ years & 60 & 17.9 & 58 & 0 & 1 & 1 & 0 & & \\
\hline >66years & 46 & 14.3 & 44 & 0 & 0 & 2 & 0 & & \\
\hline Total & 334 & 100 & 317 & 4 & 6 & 6 & 1 & & \\
\hline
\end{tabular}

Key: M.C. =Mucinous Carcinoma; Invasive ductal Carcinoma; DCIS= Ductal Carcinoma in situ (Analysis of Variance)

Table 4. National and international distribution of breast cancer in relation to subtypes, mean age and peak prevalence

\begin{tabular}{|c|c|c|c|c|c|c|c|c|c|c|}
\hline $\begin{array}{c}\text { Variables } \\
\text { (years) }\end{array}$ & $\begin{array}{c}\text { Present } \\
\text { study } \\
\text { (Ogun) }\end{array}$ & $\begin{array}{l}\text { Nwafor and } \\
\text { Keshinro, } \\
\text { [10]Lagos }\end{array}$ & $\begin{array}{l}\text { Anyanwu, } \\
\text { [11] Nnewi } \\
\text { (Anambra) }\end{array}$ & $\begin{array}{c}\text { Adisa et } \\
\text { al. [12] } \\
\text { Abia }\end{array}$ & $\begin{array}{c}\text { Forae et } \\
\text { al.[13] } \\
\text { Warri } \\
\text { (Delta) }\end{array}$ & $\begin{array}{l}\text { Ekanem and } \\
\text { Aligbe [14] } \\
\text { Benin(Edo) }\end{array}$ & $\begin{array}{c}\text { Eke et } \\
\text { al. [15] } \\
\text { Benue }\end{array}$ & $\begin{array}{c}\text { Imam et al. } \\
{[18]} \\
\text { Maiduguri }\end{array}$ & $\begin{array}{l}\text { Agbo et } \\
\text { al. [19] } \\
\text { Sokoto }\end{array}$ & $\begin{array}{c}\text { Kene et al. } \\
\text { [20] Zaria } \\
\text { (Kaduna) }\end{array}$ \\
\hline $\begin{array}{l}\text { First peak } \\
\text { age range }\end{array}$ & $41-50$ & $40-49$ & $40-49$ & $30-50$ & $40-49$ & $31-40$ & $30-39$ & $38-52$ & $41-50$ & $40-49$ \\
\hline $\begin{array}{l}\text { Second } \\
\text { peak age } \\
\text { range }\end{array}$ & $51-60$ & $30-39$ & $30-39$ & - & $30-39$ & $41-50$ & $40-49$ & $53-67$ & $51-60$ & $30-39$ \\
\hline
\end{tabular}

Table 4 above shows that breast cancer is most prevalent within the age range of $40-49$ years in the entire Nigerian Population.

\section{Discussion}

In this study, the prevalence of breast cancer among other human cancers was lower $(40.9 \%)$ than the value recorded in Abuja (50.8\%) [22] and Osun State (53.2\%) [23] and higher than the value reported in Kwara State (22.4\%) [24], Borno State (13.9\%) [18] and Benue State $(8.1 \%)$ [15], but comparable with the value recorded in Oyo State (40.8\%) [22]. This suggests that females in South-West Nigeria are relatively at a higher risk of developing breast cancer than any other region in Nigeria. The reason is yet unknown. However, it might be linked to BRCA 2 mutation which is common among individuals of African descent [25]. This study also showed increasing trend in the prevalence of breast cancer in Ogun State with the highest frequency in 2016. This is in line with the study carried out in Nigeria by Agbo et al. [20] and Oguntoke [25]. The increasing prevalence could be due to increasing western lifestyle, exposure to bacteria or viral infections, awareness, improved diagnosis or better documentation. Minoza et al. [26] reported that the North-East Nigeria is also experiencing similar increase in breast cancer presentations. In this study, women of child bearing age had the highest prevalence of breast cancer. This is in contrast to the findings of Abdulrahman et al. [27] who reported highest breast cancer presentations (two-third) among premenopausal women in Africa and among postmenopausal women in Europe. More so, the mean age of breast cancer presentations in Ogun State (50.3\%) was higher than that recorded in any Nigerian States [11-20] and Africa [28].

Based on the population of Ogun State, the decline in breast cancer prevalence after the age of 50 years (table 2) might be related to the life expectancy of people (49.1 years) in Nigeria [5]. This study also showed that the prevalence of breast cancer decreases after child bearing age (table 3 ). This is in line with other reports in literature $[29,30]$. The high prevalence of breast cancer among women of reproductive age could be related to increase in progesterone and estrogen during pregnancy and high parity while the decrease in breast cancer presentation after the reproductive age could be associated with decreased frequency of hormone surge and menopause. Surge in reproductive hormones has been reported to influence breast cancer risk by increasing cell proliferation and DNA damage or by other biological mechanisms [6]. Adisa et al. [12] also pointed out that $95 \%$ of breast cancer in Nigeria is found among multiparous women. This study showed that age ranges 41-50 years and 51-60 years had the first peak and second peak breast cancer presentation, respectively (table 4). This finding is similar to that reported by Agbo et 
al. [19] in Sokoto. This explains why breast cancer related deaths occur within the age range of 40-60 years in Nigeria [4]. Interestingly, the age-range of 60-69 years had the highest incidence of breast cancer within the population of Ogun State [31](fig. 1).

According to the World Health Organization, the most common histological type of breast cancer is the invasive ductal carcinoma (IDC) which makes up to $80 \%$ of all breast cancer diagnosis worldwide [32]. Our study revealed that IDC was the prevalent breast cancer in Ogun State. The findings of this study and that of Nwafor and Keshinro [10] suggest that invasive ductal carcinoma is relatively higher in South-West Nigeria compared with the value recorded in other geopolitical zones (fig. 2). The reason for this is yet unknown but it could be attributed to increased western life-style in the region. Additionally, this study showed that IDC is prevalent among the age range of 41-50 years. This agrees well with the findings of Agbo et al. [18] who recorded similar prevalence within the same age range. The prevalence of DCIS observed in this study was higher than that observed in Zaria [21] but lower than that observed in Nnewi, South-East [11] and Benin city, South-West [14]. While Kong et al. [33] reported a peak prevalence of DCIS among Chinese women within the age range of 40-49 years, this study did not record any case within the said age range but within the age ranges of 31-40 and 51-60 years. This suggests that location might be a contributing factor to the development of DCIS. Paget's disease is an uncommon eczematous manifestation that spreads outwards from the milk duct to areola skin resulting to its thickness. It consists of $1-5 \%$ of mammary cancer, [34] and associated with other types of breast malignancy (mostly IDC or DCIS) [35]. At the national level, only the South-West, South-South and North-Central Nigeria had cases of Paget's disease. Its prevalence in Ogun State (South-West) was higher than that recorded in Delta State (South-South) [13] but lower than that reported in Benue State, North-Central [15]. The prevalence of medullary carcinoma in this study was higher than that reported in Maiduguri [18] and Warri [13] but lower than that reported in Lagos [10], Benin [14] and Zaria [20]. This suggests that individuals in Ogun State are at low risk of developing medullary carcinoma than its neighbouring South-West State (Lagos State).. Mucinous Carcinoma is a mucin containing breast cancer surrounded by tumor cells [36]. Our study showed low prevalence of mucinous carcinoma in Ogun State compared with that found in other States in Nigeria $[10,11,13-15,18,20]$.

\section{Conclusions}

This study revealed that female breast cancer is most prevalent among reproductive age or child bearing women. This study showed that IDC, which peaks at the age range of 41-50 years, is the most prevalent type of breast cancer in Ogun State, South-West zone and Nigeria as a whole.
This study revealed that IDC, DCIS, Medullary carcinoma, Mucinous carcinoma and Paget's cell disease are more prevalent in South-West, South-East, North-West, South-East, North-Central regions, respectively. Despite the fact that the age range of 41-50 years had the highest prevalence of breast cancer, the age range of 61-70 years had the highest incidence of breast cancer in the State. Thus, women within the age range of 40-50 should be constantly sensitized and closely monitored for early signs of breast cancer.

This research is limited in the sense that breast cancer study has only been carried out in a few States in Nigeria. Thus, the data collected may not absolutely represent the epidemiology of breast cancer in the country. Hence, more studies are warranted in States devoid of published breast cancer prevalence and incidence. Such studies will go a long way to providing data for proper monitoring and intervention and in the long run reduce breast cancer related death in the Nigeria.

\section{Acknowledgements}

Authors owe a great deal of gratitude to the laboratory staff of Olabisi Onabanjo University Teaching Hospital, State Hospital Abeokuta and Federal Medical Centre Abeokuta for their technical assistance throughout the study.

\section{List of abbreviations:}

$\mathrm{BC}=$ Breast cancer; $\mathrm{N} 1=$ Total female breast cancer cases; $\mathrm{N} 2=$ Total number of human cancer presentations; №= Number; M.C. = Mucinous Carcinoma; Invasive ductal Carcinoma; DCIS $=$ Ductal Carcinoma in situ; $\mathrm{CAR}=$ Central Africa Republic, Dis $=$ Disease; $C=$ Carcinoma

\section{REFERENCES}

[1] M. Ghoncheh, Z. Pournamdar, H. Salehiniya. Incidence and Mortality and Epidemiology of Breast Cancer in the World. Asian Pacific Journal of Cancer Preview. 17(Suppl.3), S43-46, 2016.

[2] A.I. Baba, E. Hincal. Cancer Incidence in Nigeria and Border Countries. Malaysian Journal of Medical and Biological Research. 3(1), 7-12, 2016

[3] O.A. Ralph, A.A. Philps, O.A. Oguntunde, O.M. Afolayan. Cancer mortality Pattern in Lagos University Teaching Hospital, Lagos, Nigeria. J Cancer Epidemiol. 2015:1-6, 2015. doi: $10.1155 / 2015 / 842032$

[4] O.R Akinde, A.A. Phillips, O.A. Oguntunde, O.M. Afolayan. Cancer Mortality Pattern in Lagos University Teaching Hospital, Lagos, Nigeria. Journal of Cancer and Epidemiology. 2015, 1-6, 2015. doi:10.1155/2015/842032 
[5] D. Huo, F. Ikpatt, A. Khramtsov, J.M. Dangou, R. Nanda, J. Dignam, B. Zhang, T. Grushko, C. Zhang, O. Oluwasola, D. Malaka, S. Malami, A. Odetunde, A.O. Adeoye, F. Iyare, A. Falusi, C.M. Perou, O.I. Olopade. Population Differences in Breast Cancer: Survey in Indigenous African Women Reveals Over-Representation of Triple-Negative Breast Cancer. Journal of Clinical Oncology. 27, 4515-4521, 2009.doi:10.1200/JCO.2008.19.6873

[6] N. Biglia, F. Defabiani, R. Ponzone, L. Mariani, D. Marenco, P. Sismondi. Journal of Endocrine Related Cancer. 11, 69-83, 2004.

[7] A. Surakasula, G.C. Nagarjunapu, K.V. Raghavaiah . A Comparative Study of Pre- and Post- menopausal Breast Cancer: Risk Factors, presentation, Characteristics and Management. Journal of Research in Pharmacology Practice. 3(1), 12-18, 2014.

[8] V. Murthy, R.S. Chamberlain. Menopausal Symptoms in Young Survivors of Breast Cancer: A growing Problem without an Ideal Solution. Journal on Cancer Control, 19, 317-329, 2012.

[9] Endogenous Hormones and Breast Cancer Collaborative Group. Sex hormones and breast cancer risk in premenopausal women: collaborative reanalysis of seven prospective studies. Lancet Oncology. 14(10), 1009-1019, 2013.

[10] C.C. Nwafor, S.O. Keshinro. Pattern of hormone receptors and human epidermal growth factor receptor 2 status in sub-Saharan breast cancer cases: Private practice experience. Nigerian Journal of Clinical Practice. 18, 553-558, 2015.doi: 10.4103/1119-3077.156905

[11] S.N.C. Anyanwu. Temporal trends in breast cancer presentation in the third world. Journal of Experimental \& Clinical Cancer Research. 27, 17, 2008. doi:10.1186/1756-9966-27-17

[12] C.A. Adisa, N. Eleweke, A.A. Alfred, M.J. Campbell, R. Shaerma, O. Nseyo, V. Tandon, R. Mukhtar, A. Greninger, J.D. Risi, L.J. Esserman. Biology of Breast cancer in Nigeria women: A pilot study. Annals of African Medicine. 11, 69-175, 2012. doi: 10.4103/1596-3519.96880

[13] G.D. Forae, F.N. Nwachokor, A.P. Igbe. Histopathological profile of breast cancer in an African population. Annals of Medicine and Health Science Research. 2014, 4(3), 369-373. doi: 10.4103/2141-9248.133462.

[14] V.J. Ekanem, J.U. Aligbe. Histopathological types of breast cancer in Nigerian women: A 12-year review (1993-2004) African Journal of Reproductive Health. 10, 71-75, 2006.

[15] B.A. Eke, B.A. Ojo, P.D. Akaa, C.N. Ahachi, C. Soo, A. Adekwu. The Spectrum of Breast Diseases in Nigeria North Central: A Histopathological Survey. JAMPS. 13(3), 1-6, 2017.

[16] L.D. Gukas, B.A. Jennings, B.M. Mandong, G.O. Igun, A.C. Girling, A.N. Manasseh, B.T. Ugwu, S.J. Leinster. Clinicopathological features and molecular markers of breast cancer in Jos, Nigeria. West African Journal of Medicine. 24(3), 209-213, 2005. PMID:16276696

[17] A.M. Dauda, M.A. Misauno, E.O. Ojo. Histopathological types of breast cancer in Gombe, North Eastern Nigeria: A seven-year review. African Journal of Reproductive Health. $15,109-111,2011$.
[18] B.A. Imam, O.O. Okechi, K. Abdullahi, U. Abubakar, A.B Musa, N. Okorie, S. Umar, A.O. Muhammed, O.M. Mohammed, A. Zakariya, K.K. Ibrahim, A. Umar. Immunohistochemical Pattern of Breast Cancer in Maiduguri, Borno State. JCTI. 5(1),1-10, 2017. doi: $10.9734 / \mathrm{JCTI} / 2017 / 3183$

[19] P.S. Agbo, A. Khalid, M. Oboirien. Clinical Presentation, Prevalence and Management of Breast Cancer in Sokoto, Nigeria. J Women's Health Care. 3, 149, 2014. doi:10.4172/2167-0420.1000149

[20] T.S. Kene, V.I. Odigie, L.M.D, Yusufu, B.O. Yusuf, S.M. Shehu, J.T. Kase. Pattern of Presentation and Survival of Breast Cancer in a Teaching Hospital in North Western Nigeria. Oman Medical Journal. 25,104-107, 2010. doi:10.5001/omj.2010.29

[21] E. Jedy-Agbaa, M.P. Curadob, O. Ogunbiyic, E. Ogaa, T. Fabowalec, F. Igbinobad, G. Osubord, T. Otue, H. Kumaie, A. Koechlinb, P. Osinubif, P. Dakuma, W. Blattnerg, C.A. Adebamowo. Cancer Incidence in Nigeria: A Report from Population-based Cancer Registries. Cancer Epidemiology. 36(5), e271-e278, 2012. doi:10.1016/j.canep.2012.04.007.

[22] O.L. Alatise, O.O. Lawal, O.O. Olasode, A.R.K. Adesunkanmi. Breast Fine Needle Aspiration Cytology in a Nigerian Tertiary Hospital. East Central African Journal of Surgery. 16(1), 1-6, 2011.

[23] E.A.O. Afolanya, O.O.K. Ibrahim, C.T. Ayilara. Cancer pattern in Ilorin: An analysis of Ilorin cancer registry statistics. Tropical Journal of Health Science. 9, 42-47, 2012.

[24] B.G. Haffty, A. Siber, E. Matoff, J. Chung, D. Lannin. Racial; differences in the incidence of BRCA1 and BRCA 2 mutations in a cohort of early onset breast cancer patients: African-American compared with white women. Journal of Medicine and Genetics. 43, 133-137, 2006.

[25] O. Oguntoke. Spatial and Social demographic disparities of cancer morbidity in Nigeria: Patterns and Factors. Malaysian J Society Space. 2014;10(1):25-35.

[26] G.K. Minoza, D. Yawe, K.T. Mustapha, Z. Lawan, H.U. Na'aya, H.A. Nggada. Hormonal and HER2 Receptor Immunohistochemistry of Breast Cancer in North-Eastern Nigeria: a preliminary report. Journal Dental Medicine Science. 15(6), 18-23, 2016

[27] G.O. Abdulrahman, G.A. Rahman. Epidemiology of Breast Cancer in Europe and Africa. Journal of Cancer and Epidemiology. 1-5, 2012. doi:10.1155/2012/915610.

[28] O.F. Ikpat, R. Ndoma-Egba, Y. Collan. influence of age and prognosis of breast cancer in Nigeria. East African Medical Journal. 79(12), 651-657, 2002.

[29] A. Ntekim, F.T. Nufu, O.B. Campbell. Breast cancer in young women in Ibadan, Nigeria. African Health Science Journal. 9(4), 242-246, 2009.

[30] National Population Commission of Nigeria, National Bureau of Statistics: Population of Ogun State. (2016) http://nigerianstat.gov.ng/. [accessed 06.08.2017]

[31] M.V. Dieci, E. Orvieto, M. Dominici, P. Conte, V. Guarneri. Rare Breast Cancer Subtypes: Histological, Molecular and Clinical Peculiarities. Onologist. 19(8):805-813, 2014. doi:10.1634/theoncologist.2014-0108 
[32] P.F, Rambau, P.L. Chalya, M.M. Manyama, K.J. Jackson. Pathological features of Breast Cancer seen in Northwestern Tanzania: A nine years retrospective study," BMC Res Notes. 4, 214. 2011. doi:10.1186/1756-500-4-214

[33] Y. Kong, L. Yang, H. Tang, N. Lv, X. Xie. A Nation-Wide Multicenter Retrospective Study of the Epidemiological, Pathological and Clinical Characteristics of Breast Cancer In Situ in Chinese Women in 1999 - 2008. PLoS ONE. 8(11), e81055. 2013. doi:10.1371/journal.pone.0081055

[34] G.N. Sharma, R. Dave, J. Sanadya, P. Sharma, K.K. Sharma. Various Types and Management of Breast Cancer: An Overview. Journal of Advance Pharmacology and
Technology Research. 1(2), 106-126, 2010.

[35] D. Peschos, E. Tsanou, P. Dallas, K. Charalabopoulos, C. Kanaris, A. Batistatou. Mucinous breast carcinoma presenting as paget's disease of the nipple in man: A case report. Diagnostic Pathology. 3, 42-45, 2008. doi: 10.1186/1746-1596-3-42

[36] A. Dumituru, A. Procop, A. Iliesiu, M. Tampa, L. Mitrache, M. Costache, M. Sajin, A. Lazroiu, M. Cirstoiu. Mucinous Breast Cancer: A Review Study of 5 Year Experience from a Hospital-Based Series of Cases. Journal Clinical Medicine. 10(1), 14-18, 2015. 